 \\ UNIVERSITEIT \\ GENT
}

biblio.ugent.be

The UGent Institutional Repository is the electronic archiving and dissemination platform for all UGent research publications. Ghent University has implemented a mandate stipulating that all academic publications of UGent researchers should be deposited and archived in this repository. Except for items where current copyright restrictions apply, these papers are available in Open Access.

This item is the archived peer-reviewed author-version of:

Christopher Lasch's The Culture of Narcissism: The Failure of a Critique of Psychological Politics

Jan De Vos

Theory Psychology 20, pp. 528-548, 2010

The online version of this article can be found at:

http://tap.sagepub.com/content/20/4/528

To refer to or to cite this work, please use the citation to the published version:

De Vos, J. (2010). Christopher Lasch's The Culture of Narcissism: The Failure of a Critique of Psychological Politics. Theory Psychology 20, pp. 528-548. DOI: 10.1177/0959354309351764 


\title{
Christopher Lasch's The Culture of Narcissism
}

\author{
The Failure of a Critique of Psychological Politics
}

\author{
Jan De Vos \\ GHENT UNIVERSITY
}

\begin{abstract}
Christopher Lasch's bestseller The Culture of Narcissism had, beyond doubt, a significant impact-it was even read in the White House. Today it is not only still frequently taught and referenced, there are also still empirical studies conducted which try to verify Lasch's assertion of the preponderance of the narcissistic personality. This paper re-reads the book as a critique of psychologization processes, and this allows us to discern, besides the flaws in Lasch's approach, a fundamental insight which goes largely unnoticed by both Lasch's opponents and his proponents. Following this, the article will situate subjectivity within the matrix of psychology, science, psychoanalysis, and politics. In this way a critique of contemporary forms of psychologization-psychologization under globalization, as it were-is made possible.
\end{abstract}

KEYWORDS: Lasch, narcissistic personality, psychoanalysis, psychologization

The history of psychology is also the history of the processes of psychologization. Studying the late-modern processes of psychologization, it is not possible to ignore Christopher Lasch's The Culture of Narcissism (1978). For my purpose here, I start with a minimal definition of psychologization as being the phenomenon of how the psy-sciences became a hegemonic discourse delivering particular signifiers and discursive schemes for looking upon oneself and upon the world. In this sense Lasch's bestseller is beyond doubt one of the most influential attempts to analyse therapeutic culture and what he terms the advent of the narcissistic personality in the Cold War era. However, a closer reading reveals not only that Lasch's culture critique is biased by a conservative agenda, but also that Lasch went astray concerning an important point in his analysis: namely, that he considers it possible to develop a critique of psychologization working from a meta-psychological use of psychoanalysis. However, the fact that Lasch did somehow strike a deep chord, I claim, is often misunderstood by both his opponents and his proponents. We might call Lasch's fundamental insight a critique of psychological politics. In 
this paper I will argue that Lasch's, as such perfectly defendable, recourse to psychoanalysis faltered where he failed to think his own stance to the end, and where he fell back into a critique of political psychology. It is here that Lasch gets bogged down in a sterile and fruitless meta-psychological critique of the processes of psychologization. This engagement with the limits of Lasch's critique of psychological politics will, furthermore, prove useful for assessing today's post-Cold War processes of psychologization. In other words, it will offer us an insight into the place of psychology in these times of globalization. I will begin by pointing out why and how Lasch's The Culture of Narcissism should be read as a critique of psychologization

\section{The Culture of Narcissism as a Critique of Psychologization}

Therapeutic justice perpetuates childlike dependence into adulthood and deprives the citizen of legal resources against the state. (Lasch, 1978, p. 229)

... the welfare system socializes the "human costs" of capitalist production ... and helps to forestall more radical solutions. (Lasch, 1978, p. 234)

Everybody is now familiar with such critiques; in fact, so familiar that all our nuanced responses to these positions have rendered them quite superficial. The least one can say is that these criticisms are not within the central scope of today's psy-theories and psypraxes, but more than that may have changed. Consider, for example, the title of an article in the APA journal Monitor on Psychology: "Wanted: Politics-Free, Science-Based Education" (Murray, 2002). We are no longer concerned with how the psy-sciences interfere with politics, but, rather, we are concerned that politics might compromise the purity of a science-based psy-praxis. The article promotes the idea that politically motivated, fad-of-the-month educational practices should be replaced by educational techniques grounded in solid scientific evidence. Thus, some 30 years after Christopher Lasch's plea to reduce the influence of the psy-experts on our everyday life-world, this has been superseded by a plea to keep the politicians out of what is understood as the proper domain of the psy-experts.

It is useful to return to Lasch's The Culture of Narcissism (1978) in order to understand this shift. Lasch's book is often cited (possibly more referenced than read) and discussed-albeit mostly in sciences other than those connected to the psy-praxes. One reason it has continued to receive attention is that it has led to some prolonged and harsh controversies. Robert Boyers (2004) describes Lasch's book as having been fiercely criticized from the very beginning for its alleged emotional intensity and its "scornful" 
or "dismissive" tone. When faced with high-pitched emotionality, academia necessarily gets very ... emotional. Furthermore, Lasch used psychoanalytic concepts in such a compelling and engaging way to explain Tom Wolfe's idea of the "Me Decade" that in order to respond properly, critics were forced, reluctantly, to acknowledge some of his basic theoretical views. ${ }^{1}$

One of the traditional critiques of Lasch is that his study lacked empirical evidence to support the belief that pathological forms of narcissism had increased (Kilminster, 2008; Tyler, 2007). Nevertheless, as Imogen Tyler (2007) points out, Lasch's argument that an increasingly liberal, secular, affluent, and consumer-orientated post-war American society had led to the narcissistic personality quickly became established as common sense. And this might be precisely the point, the empirical fact that Lasch somehow struck a deep chord. Is this not comparable to the constitutive effect of French movie critics identifying film noir as a category in the history of American cinema? As Slavoj Žižek (2000a, p. 243) argues, it was their distant and even distorted perspective on American cinema which engendered film noir as a genre as such. Ultimately, the success of Lasch's book may have boiled down to its production of a social reality: namely, a society which regards itself as entering a narcissistic "Me Decade." It is, then, less interesting to pinpoint his misunderstandings and attempt to recover the real behind his assertions than it is to endeavour to understand how a society so easily fell into the grip of Tom Wolfe's "Me Decade" and Lasch's narcissistic personality.

In this way Richard Kilminster, in his critique of the lack of evidence underpinning Lasch's diagnosis, is absolutely right in contending that Lasch dramatizes the issue to convince his readers of his point of view (Kilminster, 2008, p. 139). The problem with such critiques, however, is that they, from their narrow empirical point of view, fail to explain why Lasch dramatized the issue of narcissism that convincingly. ${ }^{2}$ To begin with, is it not clear that Kilminster's plea for a "detached analysis of the psychic costs of current social trends" (p. 147) concerns exactly the detached, academic position the proliferation of which was criticized by Lasch? Central in Lasch's Culture of Narcissism is the critique of therapeutic culture and the growing psychologization, educationalization, and, in general, academization of everyday life: “... no aspect of contemporary thought has proved immune to educationalization. The university has boiled all experience down into "courses" of study. ... In its eagerness to embrace experience, the university

\footnotetext{
1 This may also hold true for other controversial writers, such as Slavoj Žižek, who is clearly indebted to Lasch, and whose theoretical idiosyncrasies, like Lasch's, are difficult to engage with without partially going along with them. Hence the emotional and harsh criticism their work often receives.

${ }^{2}$ For another instance of how central dramatization is in the constitution of psychological theory, see De Vos (2009).
} 
comes to serve as a substitute for it" (Lasch, 1978, p. 153). So when recent studies which revisit Lasch try to pinpoint whether or not contemporary social and behavioural trends would affect Lasch's diagnosis (e.g., Trzesniewski, Donnellan, \& Robins, 2008; Twenge, Konrath, Foster, Campbell, \& Bushman, 2008), they miss the fact that their academic and limited empirical understanding of reality is exactly what was being targeted by Lasch in the first place. Moreover, what they equally fail to account for in their narrow aim of studying how contemporary trends would affect Lasch's diagnosis is the effect which Lasch's diagnosis itself had on society. Is, for example, the very effect of Lasch's critique of narcissistic culture not that it turned our gaze inwards? In other words, is it Lasch's own stance which engendered introspective navelgazing? Here a further paradox emerges. What Lasch places in opposition to the psychologized and academified outlook on everyday life is a metapsychological point of view. Is not the first conclusion we should make here that the processes of psychologization are, themselves, essential to their own critique? In other words, Lasch is part and parcel of the psychologization processes of the 1960s and 1970s which he describes so engagingly. The critique on psychologization cannot but coincide with the very phenomenon of psychologization itself. Laying it bare makes it exist and, in this way, the critique engenders the necessary reflexive perspective central to psychologization itself. Lasch's Culture of Narcissism is, thus, foremost a landmark in a society engaged in a self-contemplative, narcissistic stance.

It is only in reading The Culture of Narcissism as a critique on psychologization and academization that a second traditional critique on Lasch, his so-called conservative leftism (see, e.g., Barrett \& McIntosh, 1982), can be reframed. Lasch is often reproached for pathologizing emancipatory politic movements. Tyler, for example, criticizes Lasch for attributing narcissism to stereotyped figures (sexually liberated women, feminists, career women, African-Americans, gays and lesbians, etc.) in order to promote white heterosexual masculine and patriarchal forms of sociality. For Tyler (2007), Lasch speaks in the interests of those sections of the American population threatened by the radical social politics of the 1960s and the 1970s. Lasch's aversion to identity politics, as it would be called today, is beyond doubt, and this does give his thesis a clearly nostalgic and conservative undertone. ${ }^{3}$ But he does not so much attribute narcissism to AfricanAmericans, for example, as point to white Americans' strange adoption and imitation of

\footnotetext{
${ }^{3}$ Identity politics is usually understood as political activity or theorizing on the basis of a cultural, racial, gender, ethnic, or other claim. Eric Hobsbawm (1996) sees the emergence of identity politics as a consequence of the "extraordinarily rapid and profound upheavals and transformations of human society" (p. 40) at the end of the 20th century, and the consequent weakening of both the nation-state and the old class-based political parties and movement.
} 
what they suppose to be a ghetto style. Furthermore, he argues that the so-called "emancipatory movements" patronized by white middle-class academia often engender precisely that which they try to combat. Lasch contends, for example, that the educational radicalism of the late 1960s not only left the status quo intact, but actually reinforced it. While striving to validate subcultures, it condemned the lower classes to a secondrate education, thereby perpetuating inequality (Lasch, 1978, p. 145). For Lasch, radical educational reformers' insistence on racial pride is a false solution. Here he quotes Kenneth Clark saying that "black children or any other group of children can't develop pride by just saying they have it, by singing a song about it" (as cited in Lasch, 1978, p. 144).

So when Barrett and McIntosh (1982) criticize Lasch's approach to feminism, and Tobin Siebers (2002) accuses Lasch of summoning narcissism "against black studies, women's studies and, more recently, disability studies" (p. 41), these critics miss the point that his critique does not concern members of political minorities as such. It concerns, rather, the studies. Even today, 30 years after Lasch's book, it is clear that the dynamics of different identity politics are essentially an academic matter. This should be questioned: What is the effect of the academic appropriation of politic struggles? Does not the term studies take the sting out of the emancipatory moment? At the very least, we should consider the effects of emancipatory movements getting caught in empirical demands, publication strategies, academic career planning, and fund-raising issues. Thus, Lasch does not essentially pathologize minority groups and their emancipatory potential; his primary target is academia. However, we should not entirely brush away the critique of Lasch's conservative undertow, which Slavoj Žižek (2000b) refers to as "neo-conservative populism" (p. 221), pointing to Lasch's arguments for the reassertion of community, local democracy, and active citizenship as the answer to the bureaucratization and instrumentalization of our life-world. Our hypothesis, rather, is that this nostalgia emerges exactly at the point where he cannot fully grasp the inherent paradoxes of academia. As Boyers puts it, Lasch's emphasis on order and authority is problematic not only because he aligns himself with conservative thinkers, but primarily because it marks a largely unacknowledged contradiction in his thinking (Boyers, 2004, p. 12). This contradiction can be understood, as we will show in the next section, as Lasch's reaching a deadlock in his attempt to ground his critique of psychologization in a metapsychological use of psychoanalysis.

\section{Lost in Psychologization}

Lasch tried to grasp the dynamics of academization and psychologization in order to get a grip on the bureaucratization and instrumentalization of our life-world. In this way he wanted to create a theoretical safe haven for the "besieged family." As just another con- 
tingent social unit, without independent weight, the family is an easy victim for both the state and the capitalist market (Anderson, 1995). In this context Lasch used psychoanalytic theory to bolster the status of the family and, thus, to safeguard it from colonization. For Lasch, neither mainstream psychology nor the mainstream critiques of psychology could accomplish this task as both misunderstand how the socialization of production proved to be the prelude to the socialization of reproduction itself (Lasch, 1978, p. 154). ${ }^{4}$ For Lasch, alongside probation officers and physicians, psychologists and psychiatrists entered the juvenile court to erode the rights of the ordinary citizen (p. 157). He is, however, also critical of oppositional movements: for example, reformers who oppose the extraction of children from their families, wanting to save the family as a whole. For Lasch, these reformers still accept the premise that the family cannot manage without external assistance (p. 160). He also points to false critiques influenced by "debased versions of Freudian theory" which promote a kind of permissiveness in the name of children's needs. Lasch refers here to Dr. Spock's Baby and Child Care (1951), which opens with the anti-expert phrase "Trust yourself." Such stances, Lasch argues, do not lead to a withdrawal of the experts; on the contrary, they only widen the scope of their claims, setting themselves up as the doctors for all of society (p. 163).

But then the question, of course, is whether Lasch himself can escape that position, whether his The Culture of Narcissism is not meant as a self-help book for the whole of society. Let us follow Lasch where he tries to analyse the cultural malaise, the discontents of his era. He writes:

Today Americans are overcome not by the sense of endless possibility but by the banality of the social order they have erected against it. ...they feel themselves overwhelmed by an annihilating boredom, like animals whose instincts have withered in captivity. (p. 11)

Lasch tries to comprehend this captivity through a Marxist framework; capitalists took production out of the household and collectivized it, appropriated the workers' skills and technical knowledge, and brought these skills together under managerial direction. At the same time they extended their control over the workers' private lives: “... as doctors, psychiatrists, teachers, child guidance experts, officers of the juvenile courts, and other specialists began to supervise child-rearing, formerly the business of the family"

\footnotetext{
${ }^{4}$ In 1910 Ellen Richards wrote: “...the child as a future citizen is an asset of the state, not the property of its parents" (as cited in Lasch, 1978, p. 155)-only recently, Ankie Vandekerckhove, a Flemish Children's Rights official argued that the government should force its way into the family as the last private cell of society ("Bemiddeling," 2004).
} 
(Lasch, 1977, pp. xiv-xv). The double alienation and double banality of this heartless world make men want to recapture something of the lost empty wilderness:

A reversion to savagery threatens them so little that they long precisely for a more vigorous instinctual existence. People nowadays complain of an inability to feel. They cultivate more vivid experiences, seek to beat sluggish flesh to life, attempt to revive jaded appetites. (Lasch, 1978, p. 11)

The confinements of modern life thus lead to a quest for the real thing. Aren't we here encountering Alain Badiou's (2003) passion for the real? Besieged by managers and psyexperts-the elimination of empty spaces via globalization has paranoiac effects (McGowan, 2005)-we look for something beyond those constraints, something firm and real. But, and here we come to a crucial question in Lasch and in the psy-critique as a whole, what is that longed-for real thing beyond alienation? At this point, Lasch makes the leap from a Marxist analysis to socio-pathology, and he begins to...psychologize. His nostalgia is a nostalgia for the pre-psychologized individual and pre-therapeutic society, and this leads him back to psychology, or, better, to meta-psychology.

Twentieth-century peoples have erected so many psychological barriers against strong emotions, and have invested those defenses with so much of the energy derived from forbidden impulse, that they can no longer remember what it feels like to be inundated by desire. (Lasch, 1978, p. 11)

Lasch's critique of psychologization and the pre-conceived haven of the family as designed by the psy-experts leads him to search for authenticity. In the process, however, signifiers like psychological barriers reinsert Lasch within a psychological discourse; he meta-psychologizes desire. As always, when one is seeking authenticity, at a given point a (meta-)theory enters the frame. Already in the introduction to The Culture of Narcissism, Lasch defends himself against the reproach of nostalgia with psychologizing arguments. For example, he resorts to the "psychoanalytic insight that loving memories constitute an indispensable psychological resource in maturity" (Lasch, 1978, p. xvii). Lasch's use of psychoanalysis as a meta-psychology runs throughout the book.

In his critique of mainstream psy-theories of sexuality, for example, Lasch (1978) remarks that the promotion of sex as a "healthy" and "normal" part of life masks a desire to divest it of the emotional intensity unavoidably clinging to it:

Today men and women seek escape from emotion not only because they have suffered wounds in the wars of love but because they experience their own inner impulses as intolerably urgent and menacing. The flight from feeling originates not only in the sociology of the sex war but in the psychology that accompanies it. (p. 201) 
Lasch's view is that, primarily, there is a psychological problem, and it is this itself which becomes psychologized in mainstream theories. Is psychologization not effectively a denial of the psychical dimension, while, unintentionally, the coercive theoretical models narrow down the subjective space? But if psychology is the problem and psychoanalysis the solution, then what is it that Lasch gives us? With his invocation of phallic breasts, vagina dentata, and castrating mothers (Lasch, 1978, p. 203), we could be forgiven for seeing Lasch as the Freudian sans merci, piling up Freudianisms and inviting rejection by the academy. The question is, however: Can Lasch guarantee that this Freudian approach will not have the same de-psychologizing effects? Take, for example, his view that late-modern culture imposes an ironic, pseudo-analytic self-awareness as a kind of "second nature." In opposition, he cites the American psychoanalyst Heinz Kohut:

Those who feel secure in the ego's ability to control the id, according to Kohut, take pleasure in occasionally suspending the secondary process (for example, in sleep or in sexual activity), since they know they can regain it when they wish to. (Lasch, 1978, p. 97)

Paradoxically this is similar to Dr. Spock's "Trust yourself"; it boils down to the advice to skip the Cartesian reflex, to put the psyche itself on hold. Furthermore, Lasch's be authentic and everything will work out fine still presupposes the mediation of the psy-expert on two accounts: first, it is the scientist who can discern authenticity from inauthenticity; and, second, it is the scientist who knows what the rewards of this authenticity are. This then engenders the quintessential questions of late-modern subjectivity: Can I be authentic? Am I normal enough? Am I human enough? Am I not always viewing my own life from an external position?

This would bring us to the more contemporary forms of psychologization, but before we turn to these, let us go beyond our critique of Lasch and try to discern what his fundamental insight into the processes of psychologization is. After all, his recourse to psychoanalysis was the right move, but, as we shall see, Lasch failed in that he thought that the relationship between psychoanalysis and the social is a simple one, presuming that psychoanalytical theory could fully cover the social and political field. Our claim is that Lasch did strike a deep chord here, which is often misunderstood by both his opponents and his proponents. We might term Lasch's fundamental insight here the critique of psychological politics. It is, however, a fundamental insight which he did not pursue to the end. 


\section{Lasch's Fundamental Insight: The Critique of Psychological Politics}

For Lasch, having displaced religion as the organizing framework of American culture, the therapeutic outlook threatens also to displace politics by transforming collective grievances into personal problems amenable to therapeutic intervention (Lasch, 1978, pp. 13-14). Lasch strongly opposes decision making becoming the prerogative of technical expertise and deplores the loss of the ethical dimension in public life in favour of consumerism (Lasch, 1985). Although he-as argued above-tends to metapsychologize the very thing he wants to rescue from psychologization and therapeutization, there is, nevertheless, in his thinking on politics, something which escapes this stance. So even if Lasch's critique begins with the presupposition that in pre-therapeutic times there was a place for genuine politics and genuine public engagement, his analysis goes beyond this and therefore supersedes the more superficial analysis of his contemporaries such as Richard Sennett (1977). For Lasch (1978), experiences of inner emptiness, loneliness, and inauthenticity are by no means unreal or devoid of social content. It is "the devastation of personal life" and not the retreat into privatism (claimed by Sennett) that needs to be criticized and condemned (p. 27). Thus, Lasch criticizes Sennett's romantic mourning for lost sincerity and authenticity in the realm of social exchange, which have apparently given way to more individualistic tendencies. For Lasch, the cult of intimacy originates not in the assertion of personality, but in its collapse (p. 30). His critique of mainstream forms of therapy is that they intensify the diseases they pretend to cure:

They do this, however, not by diverting attention from social problems to personal ones, from real issues to false issues, but by obscuring the social origins of the suffering-not to be confused with complacent selfabsorption - that is painfully but falsely experienced as purely personal and private. (p. 30)

Thus, for Lasch, a false psychologizing of the social origins of suffering is central and results in these problems being experienced as personal/private. This is pretty close to what Žižek considers critical theory should be about. It should assume not that we have the wrong idea of how things really are, but that we have the wrong idea of how in reality things are mystified (Žižek, 2005).

For Lasch, therapeutic culture is not about transforming real issues into false issues. The antagonism is already present at the level of the real issue of the social itself, which is to say we are dealing with the "social origins of the suffering" and these are subsequently psychologized within therapeutic culture. In other words, Lasch tries to situate subjectivity on the axis of the social and the suffering, or, put more concisely, he understands subjectivity as the fact of being subjected to the social or, more generally, to the outside world. It is this Spaltung, to put it in Freudian terms, this dividedness of the subject, which is then illegitimately transferred to the personal and the private in the process of psychologization. 
To push this further, Lasch's "social origins of the suffering" can be given two names: subjectivity and politics. For, are we here not very close to Marx's Critique of Political Economy? Žižek argues that the Critique of Political Economy essentially maintains the idea that the economy is itself political. For Žižek, the political class struggle permeates the entire analysis from the very beginning. Political economy is not about objective socioeconomic data, but rather it is about "data which always signal the outcome of a political struggle" (Žižek, 2006, p. 566). In the same way, Lasch's "social origins of the suffering" should be understood as indicating that the field of the social (the field of the public and the political) is itself already "psychological." The public realm is not exclusively concerned with objective social problems but is already infused by the dimension of the psychological and the subjective. This is Lasch's fundamental insight. This is his critique of psychological politics.

Let us approach this from the perspective of Lasch's critique of radical politics in the 1960s. Discussing these radicals' turn, in the 1970s, to the therapeutic discourses and practices of self-realization, Lasch claims that their original engagement with radical politics already served as a "refuge from the terrors of the inner life" (Lasch, 1978, p. 15). Their turn to politics was already a form of therapy. The therapeutic outlook of the 1970s laid bare the psychologizing undertow of 1960s radicalization. As long as politics attracts "those who seek to drown the sense of personal failure in collective action," (p. 15) it will have little to say about the personal dimension of social crisis. For Lasch, politics must explain why "personal growth and development have become so hard to accomplish" (p. 16). Put differently, therapeutic culture, for Lasch, is not a false solution for real political problems (the displacing of politics to psy-matters); rather, it is therapeutic culture which shows that the real political problems are situated in the psyrealm, or, more concisely, in the sphere of subjectivity.

This is where Lasch's stance is original, but also where the trap of metapsychology lurks. As noted above, this is where he seems to open the way to accusations of essentialism and can be understood as adopting the perspective of real politicians dealing with real psychological problems. It is where he succumbs to a critique of political psychology that his analysis of the social origins of suffering leads to a deadlock. It is not that his political analysis fails and then he starts to babble psychology. Neither is it that his psychological analysis fails and then he starts to babble politics. It is rather that he fails to theorize the very connection between politics and psychology.

To begin with, it is clear that the knot between politics and subjectivity should be understood historically, for is not the modern subject of the Enlightenment essentially a political entity? Sidetracking God led to the birth of the autonomous State, on the one hand, and what is generally believed to be the autonomous Individual, on the other. The two levels appear to define each other: no State exists without the autonomous, rational Individual (the principle of democracy) and there can be no Individual without an autonomous, rational State (the principle of the rule of law). This makes the modern subject 
both political and psychological. This intertwining is structurally problematic: to borrow Ernesto Laclau and Chantal Mouffe's terms, it inhibits the full realization of both the subject and society (Laclau \& Mouffe, 1985). The subject cannot be fully realized, cannot fully equal itself, because society is not a unified, rational whole, fully equal to itself. At the same time, society cannot attain full positive being because the individual subject never realizes full subjectivity, never equals itself. The lack of being on the one side always returns on the other.

But we have to take this line of thought still one step further, for it is at this point that academia enters as the necessary go-between: science, belonging to neither the subjective nor the political domain, is what knots the two together. Before the Enlightenment, humanity lived in a world where God was present in everything, whether living or not. This emanation, God as the common denominator, mediated humanity's presence, its being in the world. When, in the Renaissance, the word "psychology" was coined-by historians of psychology traditionally attributed to Rudolf Goclenius (15471628) - something must have changed. As Jacques Claes (1982) puts it, in a gradual process of secularization, humanity became more and more disentangled from the world and there psychology emerged as a mediator; it had to reconnect humanity with an ever-receding world. With Descartes, God was completely cut loose from the world. God was made the bearer of the link between humanity (res cogito) and the world (res extensa). La Mettrie pushed this further still by denying the res cogito any substance: the modern subject had to acknowledge that even its doubting and thinking were but aspects of the material world. This led to what Claes calls the second birth of psychology in Gustav Theodor Fechners's psychophysics. Indeed, one can understand psychophysics as a psychology that attempted to ground the physics of humanity's being of and being in the world. Fechner's psychology had to reconcile humanity with the modern, rapidly technologizing, world. It had to design a new place for humanity to inhabit.

The paradox, already present in the work of La Mettrie, however, is that this still presupposes a point from which humanity looks upon itself, a point outside res extensa: a zero level of subjectivity. The modern subject regards itself with the academic gaze, becoming an academic agent, radically cut off the world; this is where the subject is already dead, or should we say "undead"? This new Narcissus looks like one of Andreas Vesalius's skeletons, leaning on a tomb disinterestedly contemplating a skull (see the plate called "secunda ossium tabula," Vesalius, 1601). ${ }^{5}$

This is the shift Lasch misses. He fails to account for the narcissistic phenomena he encountered in the 1970s and 1980s in terms of the history of the modern subject. He

${ }^{5}$ The plate can be found at: http://portal.unesco.org/ci/photos/showphoto.php/photo/4200/size/big.546 
does not trace these phenomena back to the Cartesian subject, constituting itself via the academic gaze. Furthermore, it is important to understand the crucial role psychoanalysis played in that history. Did not Freud come in where Fechner's psychophysics failed? Freud tried to theorize not only the link between the modern subject and the world, but, most importantly, the structural failure of that link. That is where Freud situates symptoms and the unconscious. Although the Enlightenment showed God the door, the technology and science which arose in His place turned out to be structurally incapable of providing modern humanity with a place in the world, with a definite ontological status. It is precisely there, in the breaches of the project of modernity, that Freudian theory situated subjectivity. Thus, as the theory of Spaltung and Unbehagen, of the modern subject's splitting and unease, psychoanalysis created the possibility of thinking a new link between the subject and its world via the subject's symptoms. Maybe this solution, of Freudian symptomatology as a coping mechanism in relation to modernity's structural paradox, is what leaves Freud's ideas stranded in late modernity. Lasch's claim regarding psychopathology shifting to the narcissistic personality disorders could then be understood in terms of a deadlock of the Freudian paradigm. Think of Verhaeghe's idea that the traditional psychotherapies (modeled on Freudian psychoanalysis) fail to answer the so-called new symptomatology (Verhaeghe, 2007), or of Jacques-Alain Miller's assertion that psychoanalytical discourse (i.e., know your desire) became its own victim, realizing in society a kind of perversion of itself in a consumerist-hypercapitalistic discourse (i.e., free your desire; Miller, 2005).

The least one can say is that the narcissistic crisis Lasch is trying to describe is itself caught up in this history of the modern subject and in the history of the sciences themselves. Psychoanalysis played a central role in that history and, thus, is an important factor in shaping modern and late-modern culture. Lasch's critique of psychological politics falters where he misses the place of science (and the specific position of psychoanalysis in science) within modernity as the mediator of what we have called psychopolitical subjectivity. It is exactly in historicizing this constellation that one could try to account for supposed changes in the psyche of modern and late-modern humanity, right up to the present. On the one hand Lasch does try to account for the science's encroachment on humanity's life-world. He recognizes that instead of serving a general enlightenment, science actually reactivated "infantile appetites and the infantile need for illusions" in its "never-ending series of technological miracles, wonder-working drugs and cures" (Lasch, 1981, p. 32). On the other hand, however, he fails to recognize the role psychoanalysis itself played in providing the imagery for the reflexivity of the modern subject and, in so doing, he ends up reappropriating psychoanalysis as a meta- 
psychology. Just think how, in these post-psychoanalytical times, Freudianism has assumed a semi-conscious presence in advertising and entertainment, providing a cognitive mapping, as it were, for these technological miracles, these wonder-working drugs and cures. ${ }^{6}$ So, if Lasch, leaning on Kohut, can be understood to be promoting the possibility of an unmediated authentic being in the world (to be believed accessible by psychoanalytical means), he misses the paradox of modern subjectivity in its very relation to psychoanalysis and psychology.

For, is not the gist of a mediated being in the world that we are not merely conscious of the world, but that we are conscious of our consciousness? And if God was once the guarantee of this "balance exercise," in the Enlightenment science took over. Modern consciousness of consciousness meant that the birth of the modern psyche-the Cartesian subject of which Freudian psychoanalysis was the first consequent elaborationnecessitated a psychology. Psychoanalysis is never enough; it has to be topped by psychology (to amend, clarify, criticize, deform, deny, or refute psychoanalysis). Modern reflexivity thus emerges as always already trapped in its own mediation. The appropriate response here is to turn Lasch's idea around, to view psychoanalysis as the problem to which psychology provides an answer, which is to say, psychology is the lie which points to the truth which necessarily escapes psychoanalysis. It is to this dimension of the truth that I will turn in the last section, where I will try to assess today's post-Cold War processes of psychologization, starting with an engagement with the limits of Lasch's critique of psychological politics.

\footnotetext{
${ }^{6}$ Lasch also goes astray analysing so called "naïve" popular culture (Lasch, 1978, p. 95), which he still regards as something that can be scientifically and, particularly, psychoanalytically deconstructed. Lasch misses the fact that when we encounter phallic breasts and vagina dentate, it might be that popular culture itself is drawing upon psychoanalytic imagery. The presence of Freudian themes in popular culture can thus be considered the return of a repressed imaginary. Incest, oedipal constellations, castration, and so on, these are, as it were, the after-effects, the after-images of a theory now being rejected in mainstream academia. So we should not, for example, take the vulva-eye of Sauron on its phallic tower in the movie The Lord of the Rings at its face value, as do Ruth Goldberg and Krin Gabbard (2006), but instead regard it as a prime example of psychoanalytic imagery re-emerging in popular culture. This also offers one possible response to the criticism that Lasch misused and misappropriated Freudian terminology (Boyers, 2004). Lasch did not appropriate Freudian terminology for the analysis of the modern condition of subjectivity. Freud's terminology was there from the beginning.
} 


\section{Psychologization in Times of Globalization}

In The Culture of Narcissism Lasch is primarily concerned with identifying the fundamental shift in late-modern subjectivity; a shift he defined as economic man giving way to psychological man, the final product of bourgeois individualism. He writes:

The new narcissist is haunted not by guilt but by anxiety. ... His sexual attitudes are permissive rather than puritanical, even though his emancipation from ancient taboos brings him no sexual peace. ... [The narcissist] demands immediate gratification and lives in a state of restless, perpetually unsatisfied desire (Lasch, 1978, p. xvi)

Consider then this account, some 30 years later:

Indeed, instead of phobias, we meet with panic disorders. Instead of conversion symptoms, we find somatization disorder. Instead of hysterical nausea, there are eating disorders. With some exaggeration, it can be said that yesterday's docile psychoneurotic patient who dreamt of forbidden sexual activities resulting in massive feelings of guilt that lead to phobic and obsessional symptoms, that this patient has almost disappeared. Instead of that, we are confronted with the promiscuous, aggressive borderline patient who combines eating disorders with addictions and self mutilation. (Verhaeghe, 2007, p. 7)

Is Paul Verhaeghe's account somewhat belatedly describing the same shift in psychopathology? Are we dealing with shifting or returning sociopathologies? Lasch himself already had similar difficulties distinguishing his narcissistic subjectivity from earlier accounts of the modern individual. At the end of the 19th century, there were already reports of radical changes in subjectivity, and "atomizing individualism." Lasch quotes Brownson, who, echoing Marx, wrote in 1875: "....all that was dissoluble had been dissolved. All that was destructible had been destroyed" (as cited in Lasch, 1978, p. 9). So Lasch had to distinguish between his new narcissist and the old rugged individualist. If, for the latter, the world was "an empty wilderness to be shaped by his own design," then for the narcissist, the world is a mirror. Apparently free from family ties and institutional constraints, the narcissist can only overcome his insecurity by seeing his "grandiose self" reflected in the attentions of others, or by attaching himself to those who radiate celebrity, power, and charisma (Lasch, 1978, p. 10).

Lasch has a point here: in the course of the history of modernity, the world did indeed stop being that empty wildernesses. Modern subjects came to live in a charted world. The emptiness made way for a cathected world, to use a Freudian term. But, traditionally, this charting divides the world in two: our world versus the other world; the modern world versus the pre-modern world; or the cultured world versus the primitive world. Of course, this builds on the earlier antagonism between the Christian and the 
pagan (not yet Christian) world, but one can argue that with the Enlightenment, the antagonism changed decisively: science and technology dramatically accelerated the encroaching on the other world by the positive term of the antagonism; the pre-modern and un-enlightened world shriveled away. The last grand antagonism to dissolve was that between the West and the Communist world. With the fall of the Berlin Wall, we have lost the other world as such; there is no longer a world outside capitalism. And is this not precisely the source of the insecurity that Lasch describes? As the other world disappeared, did not the modern subject lose the backbone of his or her subjectivity, the outer world thus becoming a mirror of the disoriented subject? This would mean that Lasch's diagnosis of the narcissistic personality only becomes fully blown in today's post-Cold War, globalized world, showing, once again, that post-modernity is the culmination of modernity. Of course one can argue that there are still antagonisms. We need only think of how, in identity politics, the minority group is said to function as the other. It seems, however, that none of these post-modern antagonisms really opens up another space. Global space is unified under capitalism, the common denominator of both McDonald's and Mcjihad (Mitchell, 2002).

To understand this closing down of the other world, some of Žižek's remarks in his foreword to the Croatian edition of The Culture of Narcissism are very enlightening (Žižek, 1986). There Žižek writes that Lasch failed to supply us with a sufficient theoretical definition of the turning point in late capitalism which corresponds to the transition of organization man to pathological Narcissus. For Žižek, this turning point is the postindustrial transformation of the bureaucratic capitalist society of the 1940s and 1950s into a society described as permissive. Following Jaques-Alain Miller's suggestion that science, in various different forms, from expert advice to microelectronic gadgets, has become a constituent part of the everyday Lebenswelt (life-world; Miller, 2005), Žižek (1986) points out that "the blending of Lebenswelt with science radically undermines the very notion of Lebenswelt as a field of everyday pre-scientific self-understanding and pre-theoretical life practice, from which science derives its meaning". If our life-world has become inherently defined by science, then there is, by definition, nothing outside its grasp. For Žižek, any reference to a pre-scientific Lebenswelt corresponds to nothing less then a Blut und Boden ideology. Against this, he draws on Husserl to argue that "science as such, in the strict hermeneutic sense of the word, is unsignifying and as soon

\footnotetext{
${ }^{7}$ Žižek's authorship of the introduction to the Croatian edition of The Culture of Narcissism seems indicative of the fact that he is quite indebted to Lasch. This influence is apparent in, for example, his approach to virtuality (Žižek, 1995), his use of the maternal superego (Žižek, 1991) and his leftist critique of the political correctness of the mainstream Left (Žižek, 2002).
} 
as it inherently begins to encroach on the Lebenswelt, the whole loses its meaning and we find ourselves in a void." Science has not replaced the life-world or provided it with another signifying horizon; it has emptied the world of meaning. Miller (2005) qualifies this omnipresence of science in everyday life as answers without questions. Žižek sees this feature at work in three partial characteristics of our contemporary age: the role of experts in everyday life, the proliferation of micro-electronic gadgets, and advertising. This flood of answers engenders a longing to escape from this suffocating grip of science and technology, the longing to re-establish an authentic pre-scientific area within the life-world. This cult of authenticity, of course, cannot but be recuperated to that which it was endeavouring to escape:

The basic paradox of the contemporary "cult of authenticity" is that its inner constitution and driving force are a bunch of manuals which, by appearing scientifically legitimate, give the subject prescriptions on how to attain his authenticity, how to liberate the "creative potentials of his Ego", how to cast his mask and reveal his "real Ego", and how to turn to intuitive spontaneity and genuineness. (Žižek, 1986)

It is this cult of authenticity which I claim Lasch eventually did not surpass and that we must historicize. We should try to situate this ontological quest against the gradual encroaching of science on the life-world. Perhaps then it will be possible to locate the shifting positions of the subject. This basic antagonism of life-world and science allows us to better understand contemporary shifts in symptomatology and subjectivity. We will attempt to outline three such shifts.

To begin with one can say that in the course of modernity the Lebenswelt only came gradually to be under the sway of science. The hysterical symptoms which Freud encountered might have been the last vestiges of preacademia which, at the same time, functioned as a mediator between Science and the Lebenswelt. The hegemonic discourse, the transferential setting, was that of science, medical science in particular. In Lacanian terms, the transference was situated in the discourse of the master. ${ }^{8}$ The hysterical symp-

\footnotetext{
${ }^{8}$ In his seminar "L'envers de la psychanalyse" (Seminar XVII), Lacan (1969-1970/ 2007) distinguished four discourses: the discourse of the master, the university, the hysteric, and the analyst. The discourse of the hysteric is the discourse of fundamental dividedness (the Freudian "Spaltung"): for example, the patient bringing his or her symptom into the social as a question. The addressee of the hysteric is the discourse of the master, where the master, for example the doctor, produces knowledge as the (structurally failing) answer to the symptom of the hysteric. The shift in the university discourse is that the gathered scientific knowledge stands in the place of the actor. There, the so-called "master-signifier" is denied or hidden. The knowledge presents itself as plain and neutral, disavowing the performative gesture of the production of knowledge. In the dis-
} 
tom, with its reference to the dark, pre-scientific Lebenswelt, on the one hand solicited the scientist's clarifications but, on the other, it defied science. Paralyses, for example, were presented which no organic lesion could explain, migrating to other body parts after initial successful treatments. The hysterical symptom was the question without answer par excellence, defying the very structure of scientific discourse.

The second development in modern symptomatology can be seen to be connected to the further encroachment on the space of the Lebenswelt. At a certain point, symptoms became no longer signs of something pre-scientific on which science could shed some light. Rather, symptoms came to emerge directly in the language of science itself. Here the diagnosis of borderline personality disorder is exemplary. Originating from a confusion on the part of clinicians who were encountering symptoms they could not situate in the then standard dichotomy neurosis/psychosis, the diagnosis of borderline personality disorder rapidly became the first trend in the psy-world. Not only was it detected everywhere, it was also the first diagnosis to be known by a broad lay public, thus becoming one of the first popular self-diagnoses. The symptoms were offered in the transference not to a master discourse, but to science itself. That is to say, the symptoms were situated within the discourse of the university. Lay individuals became psychology students, offering their symptoms to senior scientists, as answers to be questioned, as phenomena to be tackled by academic programmes.

And are we not, quite recently, experiencing yet a third shift in symptomatology? Clinicians, as Verhaeghe points out, encounter panic disorders, somatization disorders, eating disorders, addictions, and self-mutilation. Are these contemporary symptoms, termed ADHD (Attention Deficit and Hyperactivity Disorder), CFS (Chronic Fatigue Syndrome), and PTSS (Post-Traumatic Stress Syndrome), unmediated, pure symptoms? Have we finally done away with the old transferential settings, so that behind the Freudian, Jungian, Lacanian, or other veils the real symptoms are now laid bare? Do today's symptoms thus lack the dimension of the signifier, as Verhaeghe (2007) contends? We should, however, renounce these claims. The signifiers in play are precisely those of science. For does not the fact that today's symptoms come in abbreviations testify to their discursive structure? In today's clinic, we are not dealing with pure, unmediated anxiety. We still need to look for the discursive structure, and here it is to be found in the DSM, which is widely disseminated in the popular press and on the internet. This time the framework is, thus, fully situated in science. Today the encroachment of

course of the analyst it is not knowledge which is put to work. Within the transference the analyst assumes the place of the object of desire of the analysand, which is to say he or she keeps this place empty in order to make it possible for the analysand to know about his or her desire. 
science on the life-world is complete. Contemporary symptomatology is not situated in the domain of the life-world, nor in the intersection of the life-world with science as it was in the second shift; today's symptoms are to be situated within a unified field hegemonized by science. This means that symptoms are not offered in the classical transference of the discourse of the master as answerless questions. Nor are they simply offered in the discourse of the university to authorities in psychology as questioned answers. Today symptoms are not to be discussed within a shared academic field; they only need to be acknowledged as scientific facts. Treatment is the reserve of the super-expert who treats only the body. While in the second shift, we still had a subject connected to/disconnected from his or her symptoms, the subject now need only present his or her body to the super-experts, or, more properly, to the super-technicians, as an already answered technical question. Here La Mettrie's subject as the zero level of subjectivity is finally reached.

What, then, is the proper term for the transferential setting in the third shift? If it can be understood in terms of neither the discourse of the master nor the discourse of the university, then how should we understand it? In concrete terms, contemporary symptoms can be understood to be addressed to the pharmacological discourse, a discourse which is effectively a symbiosis of academia and capitalism. To remain within the four discourses as delimited by Lacan, we could follow Miller's suggestion that the discourse of the analyst has become, in a subverted way, the dominant discourse in our society. The general social discourse is no longer the other side of psychoanalysis, but, rather, its accomplishment. According to Miller (2005, pp. 8-9), the interpretive and subversive power of the analytic discourse has turned society in the direction of the discourse of the analyst. If in Lacanian terms the analyst occupies the position of the object of desire (object a) in order that the analysand can discover his or her desire, then, owing to the interpretive and subversive power of psychoanalysis, this objet $a$ has come to hold the dominant place in society. It has become society's compass (Miller, 2005, p. 6). This would mean that hypermodern civilization is not so accurately characterized as therapeutic society as it would be as analytic society. If we follow this logic to the end, we can then say that objet petit a is exactly what the questionless answers of science are about. It is in this context, in society structured as the discourse of the analyst, that contemporary symptoms are offered as answered questions.

\section{Conclusions}

Various authors have suggested that contemporary symptoms are not amenable to the classical Freudian approach of transference and interpretation. Such writers propose that where the traditional historicizing and transferential framework is lacking, the work of construction or synthesis is necessary with the express aim of introducing the 
dimension of the signifier (see Verhaeghe, 2007). On the one hand we could ask what range of subject positions would then be promoted? What, that is, might be the ethical implications of the production of subject-prostheses by the super-expert or supertechnician? On the other hand, we should appreciate that there is a historical and discursive framework in operation here. As we have already argued, it is not that contemporary symptoms are lacking signifiers. On the contrary, it is the signifiers and the history of the psy-sciences themselves which haunt late-modern subjectivity and symptomatology. Should psychoanalysis not, thus, resist the temptation to engage in some definitive position beyond Freud, resist the temptation to search for an ultimate and unmediated ground of the symptom? For this would be to forget that our subject is the modern subject, the subject of the sciences, or, more explicitly, the subject as the very remainder of the encroaching of the sciences on our life-world. If it is only today that the real meaning of modern subjectivity fully blossoms, then the first task is to defend this zero level of subjectivity, in its very status of zero-ness, vis-à-vis all kind of attempts at construction or synthesis.

In this sense, Lasch was absolutely right in psychologizing psychologization, in showing that in psychologization one should lay bare the psychological as the Spaltung as such. His insistence on the "social origins of the suffering" opened up, albeit momentarily, the perspective of a critique of psychological politics. However, Lasch lost himself in meta-psychology, in his refusal to think his own stance through to the end. One can rightly criticize Lasch for his essentialism and for substantializing late-modern subjectivity. That is, one can criticize him for assuming the position of master. One should, however, avoid the opposite trap of adopting a position of pure anti-essentialism, claiming that his recourse to the Freudian discursive complexes represents but only one possible modern subject position. This conventionalism, of course, would be to allow the perspective of master in again by the back door, insofar as it would be to claim an absolute viewpoint from which the different contingent subject positions could be discerned.

Some anti-anti-essentialist input is thus needed to show that Freudian theory touches the truth or, in Lacanian terms, touches the Real. As noted above, Freud's psychoanalysis played a central role in the emergence of modernity. So it is history, not historicism, that can show that the Freudian subject is foremost an elaboration of the Cartesian subject. Freud laid bare the truth of the Enlightened subject; his conception of the unconsciousness explored the limits of the Cartesian project. But the truths of psychoanalysis are of such a nature that they refuse any usefulness (Brockelman, 2003). So for the Left, as the heir of the great emancipatory theories, psychoanalysis plays an important but problematic role. The Freudian skandalons (the unconsciousness, infantile sexuality, the death drive, etc.) are not amenable to positive operationalization; they stand in the way of a psychoanalytically inspired production of political alternatives. A critique of political psychology is doomed to fail. The fact that Lasch balanced on the tightrope be- 
tween nostalgia and conservatism is testament to this fundamental problem. Psychoanalysis and its skandalons are in this way part of the fundamental trauma of the Left.

Contrary, then, to Lasch, who still reserves some positive potential for psychoanalysis to formulate visions of "good society and democratic citizenship" (Lasch, 1981), it should be clear that, where the truth of the skandalons of psychoanalysis is acknowledged, psychoanalysis's effectiveness ends, and this is precisely where politics proper should enter. It is only in this way that the two-dimensional deadlock of a Lebenswelt petrified by science can be opened up. It is only in this way that we can escape the repetitive bouncing back and forth between Lasch's plea to keep science out of the Lebenswelt and current mainstream psychology's plea to keep the Lebenswelt out of science (the APA argument for a politics-free, science-based education).

\section{References}

Anderson, K. (1995). Heartless World Revisited: Christopher Lasch's Parting Polemic Against the New Class. Times Literary Supplement (London), September 22, 1995. Available at SSRN: http://ssrn.com/abstract=901085.

Badiou, A. (2003). Seven variations on the century. Parallax, 9(2), 72-80.

Barrett, M., \& McIntosh, M. (1982). Narcissism and the Family: A Critique of Lasch.New Left Review, 135, 35-48.

Bemiddeling erkennen en opvoeding ondersteunen [Acknowledging divorce mediation, supporting parenting]. (2004). De Standaard, 14 May.

Boyers, R. (2004). The culture of narcissism after Twenty-Five years. Raritan, 24, 1-21.

Brockelman, T. (2003). The failure of the radical democratic imaginary: Žižek versus Laclau and Mouffe on vestigial utopia. Philosophy \& Social Criticism, 29(2), 183-208.

Claes, J. (1982). Psychologie, een dubbele geboorte. 1590 en 1850: bakens voor modern bewustzijn. Antwerpen, Amsterdam: De Nederlandsche Boekhandel.

De Vos, J. (2009). Now that you know, how do you feel. The Milgram experiment and psychologization. Annual Review of Critical Psychology, 7.

Goldberg R., \& Gabbard, K. (2006). What Does the Eye Demand: Sexuality, Forbidden Vision and Embodiment in The Lord of the Rings. In E. Mathijs \& M. Pomerance (Eds.), From Hobbits to Hollywood: Essays on Peter Jackson's "Lord of the Rings" (pp. 265-282). Amsterdam,New York: Rodopi.

Hobsbawn, E. J. (1996). Identity Politics and the Left. New Left Review, 217, 38-47.

Kilminster, R. (2008). Narcissism or Informalization? Christopher Lasch, Norbert Elias and Social Diagnosis. Theory, Culture \& Society, 25(3), 131-151. 
Lacan, J. (2007). The seminars of Jacques Lacan: Book XVII. The other side of psychoanalysis (R. Grigg, Trans.). New York, NY: Norton. (Original work 1969-1970)

Laclau, E., \& Mouffe, C. (1985). Hegemony and Socialist Strategy: Towards a Radical Democratic Politics. London, New York: Verso.

Lasch, C. (1977). Haven in a Heartless World: The Family Besieged. New York: Basic Books.

Lasch, C. (1978). The culture of narcissism. New York: Norton.

Lasch, C. (1981). The Freudian Left and Cultural Revolution. New Left Review, 129, 23-34.

Lasch, C. (1985). Review: Historical Sociology and the Myth of Maturity: Norbert Elias's 'Very Simple Formula'. Theory and Society, 14(5), 705-720.

McGowan, T. (2005). The Obsolescence of Mystery and the Accumulation of Waste in Don DeLillo's Underworld. Critique, 46(2), 123-145.

Miller, J.A. (2005). A Fantasy. Lacanian Praxis, 1, 5-16.

Mitchell, T. (2002). McJihad: Islam in the US Global Order. Social Text, 20(4), 1-18.

Murray, B. (2002). Wanted: politics-free, science-based education. Monitor on psychology, 33(8), 52.

Sennett, R. (1977). The Fall of Public Man. Cambridge, London, Melbourne: Cambridge University Press.

Siebers, Tobin (2002). Tender Organs, Narcissism, and Identity Politics. In S.L. Snyder, B.J. Brueggemann \& R.G. Thomson (Eds.), Disability Studies: Enabling the Humanities (pp. 4055). New York: The Modern Language Association of America.

Spock, B. (1951). The pocket book of baby and child care. New York, NY: Cardinal.

Trzesniewski, R.H., Donnellan, M.B., \& Robins, R.W. (2008). Is "generation me" really more narcissistic than previous generations? Journal of Personality, 76, 903-917.

Twenge, J. M., Konrath, S., Foster, J. D., Campbell, W. K., \& Bushman, B. J. (2008). Further evidence of an increase in narcissism among college students. Journal of Personality, 76(4), 918-928.

Trzesniewski, R. H., Donnellan, M. B., \& Robins, R. W. (2008). Is "Generation Me" really more narcissistic than previous generations? Journal of Personality, 76(4), 903-917.

Tyler, I. (2007). From ‘The Me Decade’ to 'The Me Millennium', The cultural history of narcissism. International Journal for Cultural Studies, 10(3), 343-363.

Verhaeghe, P. (2007). Chronicle of a death foretold: the end of psychotherapy. Lecture, Dublin, September 2007. http://www.dcu.ie/health4life/conferences/2007/resources/Health4Life2007 Keynote Paul Verhaeghe.pdf.

Vesalius, A. (1601). De humani corporis fabrica librorum epitome. Coloniae Agripinae: typis Stephani Hemmerden. 
Žižek, S. (1986). 'Pathological Narcissus' as a Socially Mandatory Form of Subjectivity. First published in the Croatian edition of The Culture of Narcissism by Christopher Lasch (Narcisistička kultura, Naprijed, Zagreb, 1986) Translation on: http://www.manifesta.org/manifesta3/catalogue5.htm.

Žižek, S. (1991). Looking Awry: An Introduction to Lacan Through Popular Culture. Cambridge, Mass.: MIT Press.

Žižek, S.(1995). On Virtual Sex and Related Matters. In K. Gerbel \& P. Weibel (Eds.), Mythos Information. Welcome to the Wired World. Ars electronica 95 (pp. 122-129). Vienna, New York: Springer-Verlag.

Žižek, S. (2000a). Da Capo senza Fine. In J. Butler, E. Laclau, \& S. Žižek (Eds.), Contingency, hegemony, universality: Contemporary dialogues on the left (pp. 213-262). London, UK: Verso.

Žižek, S. (2000b). The Ticklish Subject. The Absent Centre of Political Ontology. London: Verso.

Žižek, S. (2002). Revolution at the Gates: Selected Writings of Lenin from 1917. New York, NYLondon: Verso.

Žižek, S. (2005, May 26). Ignorance of the chicken, or, why many Lacanians are reactionary liberals. Lecture at the Centre for Research in Modern European Philosophy, Middlesex University, London. Retrieved 29 January 2010 from http://criticalinquiry.uchicago.edu/media/zizek.shtml

Žižek, S. (2006). Against the populist temptation. Critical Inquiry, 32(3), 551-574 